\title{
REPORTING ON OCCUPATIONAL HEALTH AND SAFETY IN ANNUAL REPORTS: A LOOK AT DISCLOSURE PRACTICES IN NEW ZEALAND
}

\author{
Judy Brown \\ Frances Butcher' \\ School of Accounting and Commercial Law \\ Victoria University of Wellington
}

NZ Department of Labour, Wellington

\begin{abstract}
In recent years many organizations in New Zealand have begun to voluntarily disclose health and safety information in their annual reports. This paper considers the rationales for such disclosures and reviews the disclosure practices of 100 of New Zealand's largest employers. It utilizes an index adapted from Morhardt (2002) and good practice guidance developed by the Health and Safety Commission in the United Kingdom (HSC 2000) to evaluate both the quantity and quality of reporting. Benchmarked against these indicators, the authors conclude that there is considerable scope for improving the overall standard of health and safety reporting in New Zealand. The paper notes some current initiatives and offers suggestions to progress developments in this area.
\end{abstract}

\section{Introduction}

In recent years many organizations in New Zealand have begun to voluntarily disclose health and safety information and other employment-related indicators in their annual reports. This is in line with overseas developments, where the practice of disclosing information on social and environmental factors in addition to financial performance is becoming relatively commonplace. This practice is often described as "triple bottom line" or "sustainable development" reporting. ${ }^{2}$ Various industry groups, civil society organizations and regulatory agencies have promoted this activity and issued a variety of guidelines designed to improve the quality of reporting. ${ }^{3}$ Professional accounting bodies are also beginning to pay attention to this area. ${ }^{4}$ A number of reporting awards schemes have been instituted in an effort to encourage and reward best practice. ${ }^{5}$

This paper focuses on the disclosure of occupational health and safety (OHS) information in New Zealand. Section 2 considers the rationales for OHS reporting, placing the issues in the context of wider debates about the appropriate conceptual foundations for social and environmental accounting. Section 3 establishes a framework for analyzing OHS disclosure practices of New Zealand's largest employers and benchmarking them against international reporting guidance. It utilizes an index adapted from Morhardt (2002) and good practice guidance developed by the Health and Safety Commission in the United Kingdom (HSC 2000) to evaluate both the quantity and quality of reporting. Section 4 reports the results of our review. Benchmarked against the index developed, the authors conclude that there is considerable scope for improving the standard of OHS reporting in New Zealand. Section 5 discusses on the types of initiatives that might be used to progress developments in this area. Section 6 contains our concluding remarks.

\section{Rationales for OHS Reporting}

There are a number of conceptual frameworks for approaching social and environmental accounting. They may be broadly summarized into three categories: the business case, the stakeholder-accountability and critical theory perspectives (Brown and Fraser 2004). Proponents of these different approaches have different views about why and how this area should be developed. In this section we focus on how these debates are played out within the OHS context.

\section{Business Case Approach}

The focus in the business case approach is on highlighting the economic benefits available to employers from systematic OHS management and reporting practices. A number of overseas regulatory agencies have taken this approach. The HSC in the United Kingdom has been particularly active. In 2000 it issued a "challenge" to the top 350 businesses to report to a common standard on health and safety issues by the end of 2002 (HSC 2000, paras 42-46). It has also set up a "Ready Reckoner" website to promote the message that "good health and safety is good business". 6 Case studies demonstrate the potential cost savings available through, inter alia; less lost time, reduced absenteeism, lower regulatory costs and enhanced business reputation. The Victorian WorkCover Authority in Australia has taken a similar approach (WorkCoverSafety 1999). In New Zealand, the NZ Business Council also emphasizes business case themes for Sustainable Development, the Sustainable 
Business Network and the Ministry for the Environment (see, e.g., NZBCSD 2002; SBN and MfE 2003).

The "safety pays" approach is contentious. Cutler and James (1996) observe that it is premised on the assumption that there is no inherent conflict between the goals of workplace health and safety and organizational profitability. It is simply a matter of "educating" employers on the merits of using an accounting based approach to OHS. However, while raising awareness of the costs of injury and illness may yield benefits for workplace safety, identification of costs per se does not justify a conclusion that it will be "economically rational" for employers to improve OHS performance (ibid. p. 758).

A number of studies have pointed to threats to employee health and safety posed by production pressures (see, e.g., Nelkin and Brown 1984, Hutter 2001). Much also depends on the firm's perceptions of its OHS risks (Hopkins 1999, Department of Labour 2000). Cutler and James (1996, p. 758) charge that, in some situations - e.g. industries characterized by low pay and low profit margins - cost benefit calculations might actually encourage employers to accord safety a lower priority. This is reinforced by research that suggests that, due to information and bargaining power asymmetries, employees themselves often underestimate $\mathrm{OHS}$ risks and do not factor the full costs they bear into their employment decisions (Nelkin and Brown 1984, McGarity and Shapiro 1996). The situation is further exacerbated by long latency occupational illnesses where symptoms may not be evident until decades following initial exposure.

A similar analysis applies with respect to decisions about OHS reporting. Research suggests that voluntary disclosures in annual reports are often a response to changed societal expectations and public policy pressures; providing firms with a means of legitimizing corporate activity and warding off regulation (Walden and Schwartz 1997, Stewart and Collins 2004). Voluntary reporting is also viewed as a way of building reputation capital, signalling ethical leadership and risk management to shareholders. The reporting of "bad news". however, may provide the seeds for more strained stakeholder relationships and regulatory attention. Disclosure may also lead to increased employee/union bargaining power. As Chan and Milne (1999), put it:

"Taking a rational and cost/benefit approach to voluntary disclosure [firms] disclose only that information they perceive will increase the value of the firm. Where the perceived harm of information outweighs the benefits, the information is unlikely to be provided" (p. 267).

Thus, while firms may be happy to share OHS information in 'win-win' situations it seems unlikely they will rush to volunteer information likely to adversely impact future cash flows. This may help to explain research that suggests that companies that report internally sometimes place a low priority on providing disclosures to external parties (Tilt 2001).
There are considerable dangers in over-estimating the business case for OHS. In particular, it may encourage regulators (and the public) to overestimate the efficacy of a voluntary approach. Even if the "safety pays" lobby is correct, there is evidence that some employees at least remain skeptical, a point brought home graphically in the following quote:

"I've been at meetings where they've discussed the cost of killing someone versus the cost of a repair... I'm working at the moment on loss risk assessments... it is cheaper for someone to die than for us to do something... I'm sure it happens in a lot of industries."

A further difficulty with the business case approach is that it encourages a framing of issues from a narrow perspective. The "optimal" health and safety and reporting levels are measured from the point of view of costs and benefits to employers. Costs and benefits to employees and local communities are only factored into the analysis if there are agency implications for the employer (e.g. in terms of lost productivity, regulatory costs or reputation effects). It thus privileges private efficiency over social efficiency (Cooper and Sherer 1984). This is problematic given that research indicates that the bulk of OHS costs fall on employees, their families, and the wider community (Dorman 2000, Hopkins 1999).

It is considerations such as these that have led a number of commentators to favour a stakeholder-centred approach to social and environmental accounting (Gray et al. 1996). Stakeholder theorists view much current reporting practice as having little to do with any genuine attempt to be accountable (O'Dwyer 2003, Christian Aid 2004). External reports that are provided are often viewed as self-serving public relations documents with little substantive content.

\section{Stakeholder-Accountability Approach}

Stakeholder-accountability proponents view corporations as institutions with public obligations. Accountability in a participative democracy means "those controlling resources provide accounts to society of their use of those resources" (Gray et al. 1996, p. 37). It involves "the duty to provide an account (not necessarily financial) or reckoning of those actions for which one is held responsible" (ibid p. 38, emphasis in original).

The starting point for the stakeholder-accountability approach in OHS is that employees have a right to a safe and healthy workplace. This needs to be backed by rights to quality information to allow employees and other stakeholders to make informed decisions and to secure the accountability of employers for OHS performance. Social and environmental accounting is a mechanism that can help to internalize currently externalized OHS costs into decision-making. It also has the potential to create new visibilities, to facilitate dialogue and debate and to promote more open and transparent decision-making (Boyce 2000). 
The United Kingdom's Centre for Corporate Accountability (CCA) has urged the HSE to encompass the social as well as business benefits of public reporting. Rather than assuming - as the business case approach does - that organizations following the guidance have a commitment to sound OHS practices, the CCA observes that statutory disclosure could:

“... Allow... stakeholders to assess [employer] commitment to effective health and safety risk and how alert [they] are to the need to monitor and improve [their] health and safety performance" (CCA 2001, para 3).

The CCA has also called for the linking of performance data with national targets, ${ }^{8}$ and emphasized the importance of establishing accountabilities (e.g. identifying directors with particular responsibility for health and safety) and getting disclosure of "bad" news (e.g. enforcement notices and convictions for OHS offences) as well as "good".

From the stakeholder-accountability perspective, relevant OHS disclosures allow employees, and their representatives, to make more informed decisions about "employers of choice". They also enable them to monitor compliance with existing OHS legislation, relevant collective bargaining provisions and voluntary codes of conduct. Disclosure is also viewed as an essential prerequisite for more participatory "stakeholder" systems of governance (Trades Union Congress 1996).

Stakeholders can respond to the information provided by applying rewards and sanctions through their market decisions, direct engagement with corporates and/or lobbying for legislation (Tilt 1994, O'Rourke 2003). Accountability reporting also helps to engender a sense of trust where employers demonstrate willingness to have their actions monitored by stakeholders. Leaving employers to develop, implement and evaluate disclosures unilaterally runs too much risk of the exercise descending into a 'public relations' exercise. Genuine stakeholder engagement in the process, backed by statutory information rights and audit provisions, helps to establish the credibility of the reporting process.

Stakeholder-accountability proponents view organizations from a pluralist perspective, with employers and employees having interests in common and separate interests. They have no difficulty with the idea that social accounting can result in 'win-wins' for employers and employers where interests overlap. Workplaces that demonstrate their commitment to good employment practices may well find it easier to attract and retain quality staff. However, cracks appear in the business case where separate interests prevail. Stakeholderaccountability proponents point to research that indicates that firms are very selective about the disclosures they make and typically only present information favourable to their image (Deegan and Gordon 1996). These findings hold even when it is clear that firms do have "bad performance" to report (Christian Aid 2004, Deegan and Rankin 1996).
Regulatory authorities overseas are starting to respond to calls to go "beyond the business case" to OHS reporting. The HSC in the United Kingdom, for example, is raising issues of accountability and social responsibility more frequently (see, e.g., HSC 2003).

In the United States, a variety of "right to know" legislation has been introduced aimed at providing better access to OHS-related information. The Emergency Planning and Community Right-to-Know Act 1986 introduced the Toxics Release Inventory, which requires companies to publish the estimated emissions of potentially hazardous chemicals. Gunningham et al. (2002) report that this has created strong incentives for firms to reduce the use of chemicals to preserve their "reputation capital" and has empowered community groups.

In the New Zealand context, a District Court judge recently ordered Nuplex Industries Limited to publish details of a conviction for air pollution in its annual report, to make environmental issues a mandatory item at all board meetings for a period of 24 months, and to publish a notice to its employees detailing its breach and previous convictions. ${ }^{9} \quad$ The Judge noted that the company had presented itself as "environmentally responsible" and that its reporting of the incident in the 2002 annual report was misleading. Triple bottom line reporting requirements have also recently been introduced in the Local Government Act 2002. ${ }^{10}$

From the perspective of Governments and regulators, social and environmental accounting can be viewed as a way of infusing expectations arising from national legislation and international obligations. In the $\mathrm{OHS}$ arena, it provides a lever to encourage increased "ownership" of health and safety by corporate boards and managers and a stimulus to strengthen employee participation in the ongoing management of workplace health and safety. There is recognition that transparency can be a key driver of social change.

\section{Critical Theory Perspective}

Critical theorists view accounting as deeply embedded in broader societal relationships and conflicts. Accountants and annual reports do not merely "report reality". Rather accounting systems are ideological tools used to shape agendas and debates and "to mediate, suppress, mystify and transform social conflict" (Guthrie and Parker, 1989, p. 351).

From this perspective, social accounting is driven "by the demands of powerful interests in society" (Puxty 1986, p. 95). Employers do not merely respond to stakeholder demand for information, but actively seek to construct a particular organizational image (Neu et al. 1998); one that favours the interests of capital and helps to entrench its power. They may engage in voluntary disclosure so as to appear socially responsive and thereby pacify sociopolitical demands (Guthrie and Parker 1990, p. 166) and control the CSR agenda. Strategies may be expected to change as power relationships in the wider socioeconomic environment change. For critical theorists, the 
fact that accounting information is so often taken at face value:

"Makes its role as a mystifyer of social relations and a legitimator of power and domination the more insidious and threatening" (Puxty 1986, p. 98).

Critical theorists are particularly wary of "greenwash", where business attempts to promote an image of being socially responsible but this is merely a facade for more sinister corporate agendas. From this perspective, OHS disclosures may be used symbolically to publicly indicate interest and concern from the 'top' of the organisation but at the same time disguise hidden agendas to preserve managerial prerogative (Hutter 2001, p. 139). It may be scen as a "tool of regulatory resistance"; with audits and cost benefits analyses becoming "as much a form of mystification as an analytical tool" (ibid).

Rather than relying on concepts such as "stakeholder dialogue", which fail to take account of the imbalances of power between capital and labour,, critical theorists prefer to utilise "anti-reports" and similar mechanisms to expose the fundamental contradictions of capitalism (see, e.g., Springett 2003, Tinker et al. 1991).

\section{A Framework for Analysing OHS Disclosures}

The analysis aimed to determine the current level of OHS reporting activity among New Zealand's largest employers, and to assess the quality of the information reported.

An essential stage in any content analysis study is deciuing which documents to analyse (Krippendorff 1980). There has been little methodological consistency between different studies assessing the content of corporate social reporting (Milne and Adler 1999). Annual reports are regarded as important documents in CSR due to the high degree of credibility they lend to information reported in them, their use by a number of stakcholders and their widespread distribution (Unerman 2000, p. 669). However, an exclusive focus on annual reports is likely to result in an incomplete picture of reporting practices.

Unerman (2000) observes that a large proportion of CSR is published in documents other than annual reports, and that lluctuations in the volume of CSR in annual reports is not a proxy for fluctuations in the volume of CSR in all regularly produced corporate reports. He concludes that studies that only examine annual reports risk underestimating the volume of CSR companies engage in (ihid. p. 673; see also Gray et al. 1995).

Arguments regarding quantification in content analysis studies largely concern whether to count sentences or words, whether differences in grammar between authors could skew results and what to do about non-narrative information such as photographs or charts: "a key assumption underlying much CSR research using content analysis was that the quantity of disclosure signified the importance of the item being disclosed" (p.668), and suggested that different measurement techniques may lead to different impressions of the relative importance of each disclosure category.

To reflect the trend of issuing standalone environmental and/or social impact reports, this study did not focus exclusively on annual reports. Letters sent to Chief Executives requested any publicly available monitoring information, including but not limited to, annual reports, triple bottom line reports, corporate social responsibility reports and environmental or health and safety reports.

\section{Collecting the data}

A sample of 100 employers was deemed sufficient for the analysis, based on available resources and the amount of data it would generate. A list of New Zealand's 200 largest employers using FTE employees was provided by ACC. The initial response rate to the first 100 letters and follow up phone call was $50 \%$. $^{\prime \prime} 13$ organisations referred to website reports in which case these were downloaded and added to the analysis. 4 organisations stated their reports were not publicly available, while 53 sent no reports despite the follow-up call. The second batch of 100 letters used the same contact methods. Once 100 reports were received in total, the sample was deemed complete and no more reports were analysed.

The sample of 100 employers fell into four size ranges:

\section{- 6 employers had $10000+$ FTEs;}

- 13 employers had 5001 - 9999 FTEs;

- 71 employers had 1000 - 4999 FTEs; and

- 10 employers had less than 1000 FTE employees. ${ }^{12}$

The largest industry in the sample was Government administration \& defence, with 24 employers, followed by manufacturing, with 19 employers. No employers in the final sample were from the agriculture, forestry \& fishing or mining or electricity, gas \& water supply or accommodation, cafes \& restaurants industry groups.

Data was extracted from all information that was provided, using the methodology outlined below. It was then analysed using an Access database.

\section{Assessing the reports' contents}

The similar OHS legislative frameworks between New Zealand and the United Kingdom meant the published HSC guidance for OHS reporting provided a good basis for comparison with New Zealand reporting.

This study used the 2000 published guidance (HSC 2000). Later versions of the guidance (which has since become a draft standard undergoing consultation (HSE 2004)) became more proprietary and localised, referring to UK specific legislation therefore requiring significant alterations if it was to be used in the New Zealand context. Based on previous Department of Labour 
research, a limited number of OHS indicators were added to provide specific, supplementary information on New Zealand's workplace practices (Department of Labour, 2003).

\section{Selecting the scoring system to quantify results}

It was decided to bypass the arguments surrounding methods of quantifying CSR and instead assess the reports against established guidance. Unfortunately, the selected HSE UK guidance had no attached scale on which to rate quality.

The Pacific Sustainability Index ('PSI') developed by Morhardt (2001, 2002, et al 2002) incorporated the UNEP Global Reporting Initiative GRI 2000 (updated 2002) sustainability reporting guidelines and other international standards such as the ISO 14031 environmental performance evaluation standard. ${ }^{13}$

Because the PSI covers all areas of sustainability, workplace health and safety was limited to one small section of the survey and was therefore insufficiently detailed for the purposes of this study. However the PSI scale (and its rules for assigning score levels) was used with the HSC guidance to score the New Zealand reports.

The PSI scale avoids a common problem experienced with scoring systems. Similar mid-level aggregate scores for two reporters, for example, could obscure that one of them reports on only a narrow range of items, but in much detail, while the other covers all items, but in vague rhetoric. (Milne et al. 2004, p. 42). The PSI instead rates the information for the quality and depth of the information provided, apart from its inclusion.

\section{Data analysis}

Various hypotheses have been advanced regarding the location of CSR information within corporate reports. Including health and safety statistics in the financial and operational highlights or a 'review of the year' may imply it is seen as integrated into the company's activities and is more than a 'personnel' issue, which may be the impression given if it is located in the 'people' section (Gray et al 1995). ${ }^{14}$

\section{Ensuring coder reliability}

The PSI scale included clear and complete descriptions of the categories and items along with comprehensive criteria and guidelines for scoring each item. This criterion was used to measure the information against the HSC guidance. Further criteria from the 2003 stock-take indicators were developed by repeating either the exact PSI criteria, or including similar criteria. Further rules for interpretation were developed during the quality control process, where every tenth report was coded independently, any divergence discussed and an approach agreed upon.

\section{Presenting the results}

The first level of data analysis summarised results by question, aggregating results across the entire sample. Particular points of interest were broken down into industry groups to provide more detailed comparison.

\section{Disclosure Practices of Top 100 New Zealand Employers}

\section{Principles}

Nearly $60 \%$ of employers provide some sort of broad statement about their health and safety policy. The most common principles given for considering health and safety are a concern for the safety, health and welfare of employees, and a concern to provide a safe place to work (20 examples each). The next most common example is recognition of the legal requirement to address occupational health and safety issues (mentioned in 11 reports).

While 41 employers report on current progress or forthcoming plans, fewer report on their goals against which this progress might be measured ( 27 examples). According to the HSC Guidance (HSC 2000), a goal of no accidents/zero injuries was not acceptable as a standalone statement. Only 16 employers reported the significant risks faced by their employees. Twenty-nine employers reported on the arrangements they made for consulting their employees (see below).

\section{Monitoring}

Roughly a third of the sample group report injuries, most often as Lost Time Injuries (LTI), but this is not a single consistent method of measurement. It is given as a number or a rate, and the method of calculating the rate varies from report to report. ${ }^{15}$ The next most common methods of monitoring are by sick leave, injury number (using a range of denominators) and by fatality. 13, 11, and 10 employers report these respectively (see Table 2).

Whereas injury (lost time or otherwise) are reported across a range of industry types, sick leave is largely reported by the health and community services industry $(80 \%)$, and fatalities by the manufacturing industry and the similar high-risk industries, communication services, construction, and transport and storage (together 90\%).

Five employers mention health and safety enforcement notices or convictions, and more often it is the lack of notices or convictions that is reported. More employers mention convictions than enforcement notices - only two mentioned notices (neither received any), where all five mentioned convictions (two received one each).

\section{Other indicators}

Twenty-nine employers report on staff turnover. Of these, 10 are government administration and defence, and 9 are health and community services. Of the 82 employers in the ACC partnership programme, 33 
employers (or $40 \%$ ) mention their participation. Of the 15 employers from the health and community services industry, 4 report the full or partial achievement of the Ministry of Health's Health and Disability Safety standard (NZS 8134:2001), and 8 on the full or partial achievement of the National Mental Health Sector standard (NZS 8143:2001).

Table 1: Health and safety performance

\begin{tabular}{|c|c|c|c|c|c|c|}
\hline Industry type & $\begin{array}{c}\text { Number or rate } \\
\text { of injuries, } \\
\text { illnesses and } \\
\text { dangerous } \\
\text { occurrences }\end{array}$ & $\begin{array}{l}\text { Details of any } \\
\text { fatalities and } \\
\text { preventative } \\
\text { actions }\end{array}$ & \begin{tabular}{|c|} 
Number of \\
employee \\
days lost (lost \\
time injuries)
\end{tabular} & $\begin{array}{l}\text { Details of any } \\
\text { health \& safety } \\
\text { enforcement } \\
\text { notices }\end{array}$ & $\begin{array}{c}\text { Details of any } \\
\text { health \& } \\
\text { safety } \\
\text { convictions }\end{array}$ & $\begin{array}{c}\text { Total } \\
\text { number of } \\
\text { employers } \\
\text { by type }\end{array}$ \\
\hline $\begin{array}{l}\text { Communication } \\
\text { services }\end{array}$ & $50 \%$ & $50 \%$ & $75 \%$ & 0 & 0 & 4 \\
\hline Construction & $100 \%$ & $100 \%$ & $100 \%$ & 0 & 0 & 1 \\
\hline $\begin{array}{l}\text { Cultural \& } \\
\text { recreational } \\
\text { services }\end{array}$ & 0 & 0 & 0 & 0 & 0 & 1 \\
\hline Education & 0 & 0 & 0 & 0 & 0 & 11 \\
\hline $\begin{array}{l}\text { Finance \& } \\
\text { insurance }\end{array}$ & $17 \%$ & 0 & $17 \%$ & 0 & 0 & 6 \\
\hline $\begin{array}{l}\text { Government } \\
\text { administration \& } \\
\text { defence }\end{array}$ & $21 \%$ & 0 & $17 \%$ & 0 & 0 & 24 \\
\hline $\begin{array}{l}\text { Health \& } \\
\text { community } \\
\text { services }\end{array}$ & $20 \%$ & 0 & $53 \%$ & 0 & 0 & 15 \\
\hline Manufacturing & $37 \%$ & $26 \%$ & $63 \%$ & $11 \%$ & $26 \%$ & 19 \\
\hline $\begin{array}{l}\text { Personal \& other } \\
\text { services }\end{array}$ & $50 \%$ & $50 \%$ & 0 & 0 & 0 & 2 \\
\hline $\begin{array}{l}\text { Property \& } \\
\text { business services }\end{array}$ & $14 \%$ & 0 & $43 \%$ & 0 & 0 & 7 \\
\hline Retail trade & 0 & 0 & $75 \%$ & 0 & $25 \%$ & 4 \\
\hline $\begin{array}{l}\text { Transport \& } \\
\text { storage }\end{array}$ & 0 & $20 \%$ & $40 \%$ & 0 & 0 & 5 \\
\hline Wholesale trade & 0 & 0 & 0 & 0 & 0 & 1 \\
\hline
\end{tabular}

\section{Table 2: Methods of Monitoring}

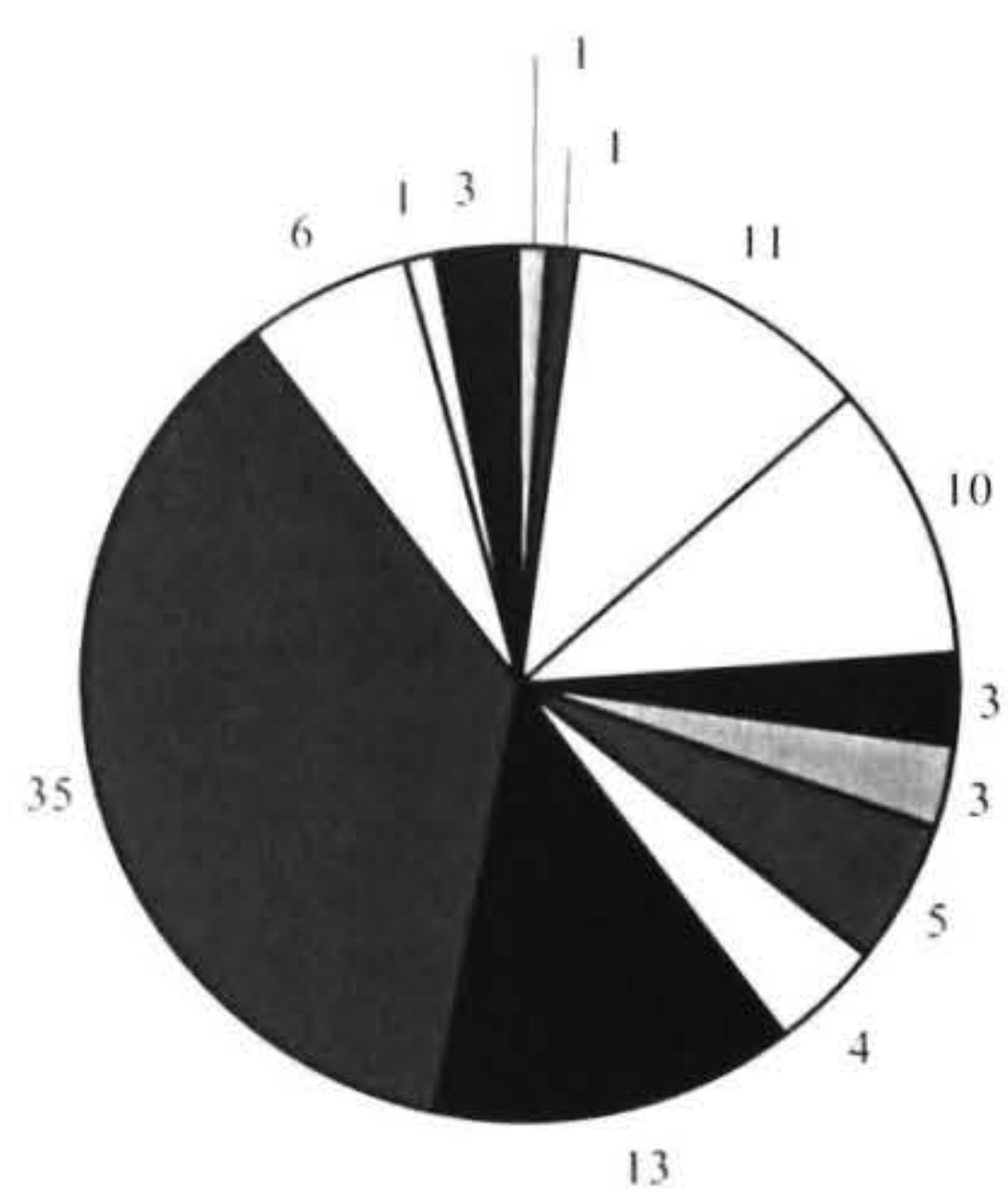

口Workplace assessments

- Inmate/staff assaults

$\square$ Injury number

口Fatalities

Injury cost

口Claims cost

Medical treatment measure

$\square$ Total incidence measure

- Sick leave

DLost time measurement

$\square$ Severity measurement

$\square$ Accident classification

Near-miss/non-injury incidence 


\section{Programmes}

Half the sample groups report on health and safety programmes or actions. Most of these (48 examples) are education or training programmes. Within that group, the largest single programme, with 28 examples, is "staff training in health and safety", rather than specific courses such as first aid or fire warden training (five and three examples each).

The second largest type of programme is auditing, with 44 examples. Most of these are internal standards, policies or guidelines (11), internal auditing (9), and reporting to management (9). The third largest type is for employee participation (42 examples), most of which are health and safety committees (17 examples) or representatives (15 examples). After "staff training in health and safety", these are the second and third largest single example.

It is notable that as a proactive programme, the use of health and safety awards, whether internal or external awards, is almost exclusively limited to the manufacturing industry, who provide five examples of each - the construction industry is the only other industry to mention awards (in this case one example of the use of external awards).

\section{Improving the Quality of OHS Reporting in New Zealand}

There are a number of ways in which OHS reporting, and indeed employee-related reporting more generally, might be improved. We consider that a tripartite approach involving government agencies, employers and unions offers the best prospects for advancement. Other parties that could usefully be included in stakeholder engagement processes include representatives from ethical investment funds, consumer organizations and NGOs (e.g. those with a focus on human rights).

In particular, the quality and completeness of reporting needs to be addressed. At present many important dimensions of OHS performance are omitted. Engaging workplace representatives (e.g. unions and health and safety committee representatives) and OHS professionals in the process of developing indicators should help to ensure more balanced reporting. Ideally, a standardized set of definitions and performance measures might be developed, with room for sector-specific considerations. This might also include differential reporting guidance (e.g. simplified reporting regimes for SMEs). There are a number of established international reporting frameworks that could be of assistance here. ${ }^{16}$ A full set of indicators could be formulated for internal use (e.g. by health and safety committees), with summary information provided in annual reports. A joint approach to the development and monitoring of OHS indicators would cohere well with the concept of workplace participation which the Health and Safety Employment (HSE) Act seeks to encourage. ${ }^{17}$
Government agencies have an important role to play in this process. The Department of Labour is currently following the lead of the HSE in the United Kingdom (see, e.g., HSC 2000, 2003) and promoting efforts to raise both the quantity and quality of OHS reporting through its government-wide Workplace Health and Safety Strategy. This involves co-ordinating stakeholder initiatives aimed at encouraging more consistent, complete and credible reporting on employment issues. It is currently gathering information on international developments and best practice examples from New Zealand and overseas to disseminate through its website as part of the Strategy (Department of Labour 2004). The Accident Compensation Corporation could require employers to establish OHS reporting systems to qualify for ACC levy discounts through the Partnership Programme and Workplace Safety Management Programme. Government agencies could publish league tables of the top 100 New Zealand employers, both in terms of the quality of reporting and OHS performance itself. The government is currently building in social and environmental reporting requirements through a range of sustainable development initiatives, including government procurement policies. ${ }^{18}$

For the reasons canvassed in Section 3, we are not convinced that a voluntary approach to OHS reporting is sufficient. The "business case" will take disclosure only so far. Regulators need to consider a broader range of costs and benefits (including costs borne by employees, local communities, taxpayers and future generations) and to remain cognisant of the accountability issues at stake. Employees have OHS rights and, arguably, a right to information that enables them to assess employer performance and participate effectively in workplace decision-making. Shareholders, consumers and NGOs are also showing increasing interest in this area. We consider that a strong argument can be made for listed companies to be legally required to disclose standard $\mathrm{OHS}$ indicators in their annual reports as part of a wider set of employment-related indicators. This would provide a useful supplement to the information rights that currently exist under the HSE Act and the good faith requirements of the Employment Relations Act (Davenport and Brown 2002).

Concerns about disclosure bias and the (in)completeness of reporting also highlight the importance of paying attention to verification and audit issues. Independent, third party assurance is widely recognized as a requirement to enhance the quality and credibility of the disclosure process. AccountAbility recently released its AA1000 Assurance Standard: Guiding Principles (2003) together with a set of guidance notes in response to growing concerns about the quality of disclosures in annual reports. They are designed to help ensure that reports provide accurate and balanced representations of organizational performance and underlying systems and processes. Stakeholder engagement is emphasized as a way of improving accountability and performance. ${ }^{19}$

In 2002 the Institute of Chartered Accountants of NZ established a taskforce to investigate sustainable 
development reporting. The taskforce identified several key issues, including the extent to which such reporting fits within the existing conceptual framework for external reporting and auditing of financial information (ICANZ 2002). A sub-committee of the Financial Reporting Standards Board has been established to pursue these issues. Hopefully this will also contribute to informed development of the area. However, as Gray (2004) observes, the accounting profession has not exactly led the charge in efforts to lift corporate social reporting standards. Indeed some elements are quite hostile to the idea of expanding the realm of accounting beyond the arena of shareholders and the capital markets. The Institute of Chartered Accountants in England and Wales has lobbied against attempts to include mandatory reporting on OHS and other elements of 'human capital management' in annual reports (ICAEW 2003). Thus it would seem unwise to leave this activity to accountants alone.

\section{Concluding Remarks}

While it is encouraging to see employers disclosing health and safety information in their annual reports, we consider that disclosure practices in New Zealand still have a long way to go in terms of both the quantity and quality of reporting. There is considerable room for improvement of OHS disclosures in terms of completeness, consistency, verifiability and comparability (see also Milne et al. 2003, on triple bottom line disclosures in New Zealand more generally). Attention needs to be paid to both the content of reports and the reporting process (e.g. in terms of stakeholder engagement and audit). We hope this article will provide organizations and interested stakeholders with some ideas for taking reporting practices forward. We consider that much can be gained by drawing on existing frameworks and guidelines for sustainable development reporting and auditing (c.g. the GRI and AA1000 frameworks). ${ }^{20}$ We have provided examples of the types of initiatives that might be pursued to progress developments in this area.

Growing numbers of writers are pointing to the fact that social reporting has been treated as something of a poor cousin to environmental reporting (Deegan 2002, p. 285), in terms of both theoretical and practical developments. There is increasing recognition that the employment arena is one with considerable research potential. We encourage ongoing monitoring by employers, workplace and community stakeholders, policymakers and researchers of national and international developments in this area.

\section{Notes}

I This paper is based on research conducted as part of a Department of Labour 'Triple Bottom Line' project. However, the views and conclusions expressed are those of the authors alone and do not necessarily rellect Department of Labour policy.
2 See Gray and Milne (2002)

3 See, e.g., the Global Reporting Initiative sustainability reporting guidelines (GRI 2002) and the AccountAbility AA1000 framework of social accounting standards (AccountAbility 1999, 2003).

4 In New Zealand, the Institute of Chartered Accountants of NZ has issued a Report of the Taskforce on Sustainable Development Reporting (ICANZ 2002).

5 One of the longest standing awards schemes is offered by the Association of Chartered Certified Accountants in the United Kingdom (see ACCA 2004). ICANZ offers awards in sustainable developing reporting and human resource reporting (see http://www.icanz.co.nz for details).

6 http://www.hse.gov.uk/costs/index.asp.

7 Middle level, blue-collar worker cited in HSE (1999, p. 21). See also Nelkin and Brown (1984).

8These include targets established by the UK Government (HSC 2000) and related union participation agreements (e.g. HSE 2002).

9. Auckland Regional Council v Nuplex Industries Limited, DC AK CRN2004066321 [18 March 2003].

10 The 2004 amendment required councils to report on the social, economic, environmental and cultural well being of the community (see Part 3 of Schedule 10).

II This response rate may be partially attributed to some employers believing that because their reports had no triple bottom line reporting in them, that they were not suitable for inclusion.

12 A full list of employers and demographic details are available from the authors.

13 Used by permission from the author. The PSI is also available on the internet: http: //www.mckenna roberts.edu

14 See Gray et al. (1995) for further discussion regarding the location of CSR information and what it implies.

15 Lost Time Injuries use the total time lost to injury divided by a variety of denominators i.e days (full day, shift day, including or exclusing weekends); hours (one hundred hours, one million hours etc).

16 See, e.g., European Chemical Industry Council (1998), Social Accountability International's SA8000 system (available at http://www.sa-intl.org/SA8000), National Occupational Health and Safety Commission (2003), World Business Council for Sustainable Development (2004), Global Reporting Initiative (2004). Despite New Zealand being a 
nation of small to medium enterprises, enterprise size is not necessarily an impediment to integrating sustainable practices. Seven employers are part of the GRI programme; one of these - Tall Poppies - has seven employees. http://www.globalreporting.org.

17 Under Section 19 of the HSE Act places of work with more than 30 employees must develop heath and safety worker participation systems.

18 See, e.g., the Ministry for the Environment's Govt ${ }^{3}$ programme,

http://www.mfe.govt.nz/issues/sustainableindustry/govt $3 /$ index.html

19 See Owen, Swift and Hunt (2001) on the importance of this being genuine dialogue.

\section{Acknowledgments}

The authors gratefully acknowledge the work of Andrew Stewart-Loughnan in collecting and analysing the data, and providing valuable feedback on drafts.

\section{References}

AccountAbility (2003). AA1000 Assurance Standard: Guiding Principles, London: AccountAbility.

AccountAbility (1999). AA1000 Framework, London: AccountAbility.

Association of Chartered Certified Accountants (2004). UK Awards for Sustainability Reporting 2003 - Report of the Judges. London: ACCA.

Boyce G. (2000). Public discourse and decision-making. Accounting Auditing \& Accountability Journal, 13(1), 27-64

Brown, J. and Fraser, M. (2004). Competing discourses in social and environmental accounting, WP 12, Centre for Accounting, Governance and Taxation, Wellington: VUW, $26 \mathrm{pp}$.

Centre for Corporate Accountability (2001). CCA Response to Draft HSE Document, London: CCA.

Chan, C.C.C. and Milne, M.J. (1999), Investor reactions to corporate environmental saints and sinners: An experimental analysis, Accounting and Business Research, 29(4), 265-279.

Christian Aid. (2004). Behind the Mask - The Real Face of Corporate Social Responsibility, London: Christian Aid.

Clarke, J. and Gibson-Sweet, M. (1999). The use of corporate disclosures in the management of reputation and legitimacy: a cross sectoral analysis of UK Top 100 Companies. Business Ethics: a European Review, 8 (1), 5-13.
Cooper, D.J. and Sherer, M.J. (1984). The value of corporate accounting reports: Arguments for a political economy of accounting. Accounting. Organizations and Society, 9(3/4), 207-232.

Cutler, T, and James, P. (1996). Does safety pay? A critical account of the Health and Safety Executive document: 'The costs of accidents'. Work, Employment \& Society, 10(4), 755-765.

Davenport, G. and Brown, J. (2002). Good Faith in Collective Bargaining. Wellington: LexisNexis.

Deegan C. (2002). The legitimising effect of social and environmental disclosures - a theoretical foundation. Accounting, Auditing and Accountability Journal, 15(3), 282-311.

Deegan, C. and Gordon, B. (1996). A study of the environmental disclosure practices of Australian corporations. Accounting and Business Research, 26(3), 187-199.

Deegan, C. and Rankin, B. (1996). Do Australian companies report environmental news objectively? Accounting, Auditing and Accountability Journal, 9(2), 50-67.

Department of Labour (2004). Workplace Health and Safety Strategy for New Zealand to 2015: draft for consultation. Wellington: DoL.

Department of Labour. (2003). Health and Safety Reporting in the Annual Reports of New Zealand's 100 Largest Employers. Wellington: DOL. (website publication forthcoming)

Department of Labour (2000). The Costs and Benefits of Complying with the HSE Act 1992. The Department of Labour Occasional Paper Series 2001/4. Wellington: DOL with the Ministry of Economic Development.

Dorman, P. (2000). The Economics of Safety, Health and Well Being at Work: An Overview, Geneva: ILO.

European Chemical Industry Council (1998). Responsible Care: Health, Safety and Environmental Reporting Guidelines.

European Commission (2002). Corporate Social Responsibility: A Business Contribution to Sustainable Development. Brussels: EC.

Global Reporting Initiative (2004). Health and Safety Protocol - Draft for Public Comment. Amsterdam: GRI.

Global Reporting Initiative (2002). Sustainability Reporting Guidelines. Boston: GRI. 
Gray, R. (2004), Why is Social Accounting So Difficult? - Part 1. Social and Environmental Accounting, 24(1), 12-17.

Gray, R. and Milne, M.J. (2002). Sustainability reporting: Who's kidding whom? Chartered Accountants Journal of New Zealand, 81(6): 6670.

Gray R., Owen D. and Adams C. (1996). Accounting and Accountability - Changes and Challenges in Corporate Social and Environmental Reporting. London: Prentice Hall.

Gray, R., Kouhy R. and Lavers S. (1995). Methodogical themes: constructing a research database of social and environmental reporting by UK companies. Accounting, Auditing and Accountability, 8(2) 78-101.

Gray, R., Kouhy R. and Lavers S. (1995). Corporate Social and Environmental Reporting: a review of the literature and a longitudinal study of UK disclosure. Accounting, Auditing and Accountability Journal, 8 (2), 47-77.

Gunningham, N. Kagan, R.A. and Thornton, D. (2002). Social licence and environmental protection: Why businesses go beyond compliance, DP 8, Centre for Analysis of Risk and Regulation, London: LSE, 25 pp.

Guthrie, J. and Parker, L. (1990). Corporate social disclosure practice: A comparative international analysis, Advances in Public Interest Accounting, 3. 159-173.

Guthrie, J. and Parker, L. (1989). Corporate social reporting: A rebuttal of legitimacy theory. Accounting and Business Research, 19(76), 343352.

Health and Safety Commission (2003). Corporate responsibility for accountability for health and safety: DTI consultation on the OFR Working Group on Materiality, London: HSC.

Health and Safety Commission (2000). Revitalising Health and Safety: London: HSC.

Health and Safety Executive (2004). The development of a health and safety management index for use by business, investors, employees, the regulator and other stakeholders. Contract Research Report 217/2004, London: HSE.

Health and Safety Executive (2002). HSE, employers and unions agree on targets to reduce injuries in the food and drink manufacturing industries, HSE press release 9/1/2002.
Health and Safety Executive (1999), Safety Cultures: Giving Staff a Clear Role, Contract Research Report 214/1999, London: HSE.

Health and Safety Executive (1998). Factors Motivating Proactive Health and Safety Management. Contract Research Report 179/1998, London: HSE.

Hopkins, A. (1999). For whom does safety pay? The case of major accidents. Safety Science, 32, 143153 .

Hutter, B.M. (2001). Regulation and Risk Occupational Health and Safety on the Railways, Oxford: Oxford University Press.

Institute of Chartered Accountants of England and Wales (2003). The Operating and Financial Review and Human Capital Reporting: Is the OFR the Place for Human Capital Reporting?, London: ICAEW.

Institute of Chartered Accountants of New Zealand (2002). Report of the Taskforce on Sustainable Development Reporting. Wellington: ICANZ.

Krippendorff, K. 'Content Analysis: An Introduction to its Methodology'. Sage Publications, Newbury Park, CA. 1980.

McGarity, T.O. and Shapiro, S.A. (1996). OSHA's critics and regulatory reform. Wake Forest Law Review, 31, 587-646.

Milne, M.J., Tregidga, H. and Walton, S. (2003). The triple bottom line: Benchmarking New Zealand's early reporters. University of Auckland Business Review, 5(2), 1-14.

Milne, M.J., and Adler, R.W. Exploring the reliability of social and environmental disclosures content analysis. In Accounting, Auditing and Accountability Vol 12 no.2 p237-56.

Morhardt, J.E. (2002). Clean Green, and Read All Over: Ten Rules for Effective Corporate Environmental and Sustainability Reporting, Milwaukee: ASQ Quality Press.

Morhardt, J. E (2001). Scoring Corporate Environmental Reports for Comprehensiveness: A Comparison of Three Systems, Environmental Management, 26(6): 881-892.

Morhardt, J. E., Baird, S. and Freeman, K. (2002). Scoring Corporate Environmental and Sustainability Reports Using GRI 2000, ISO 14031 And Other Criteria, Corporate Social Responsibility and Environmental Management, 9, 215-233. 
National Occupational Health and Safety Commission (2003). OHS Performance Measurement in the Construction Industry: Development of Positive Performance Indicators. Australia: NOHSC.

Nelkin, D. and Brown, M.S. (1984). Workers at Risk: Voices from the Workplace, Chicago: University of Chicago Press.

Neu, D., Warsame H. and Pedwell K. (1998). Managing public impressions: Environmental disclosures in annual reports. Accounting, Organizations and Society, 23(3), 265-282.

NZ Business Council for Sustainable Development (2002). Business Guide to Sustainable Development Reporting, Auckland: NZBCSD.

O'Dwyer, B. (2003). Conceptions of corporate social responsibility: The nature of managerial capture, Accounting, Auditing and Accountability Journal, 16(4), 523-557.

O'Rourke, A. (2003). A new politics of engagement: Shareholder activism for corporate social responsibility. Business Strategy and the Environment, 12, 227-239.

Owen D.L, Swift T. and Hunt K. (2001). Questioning the role of stakeholder engagement in social and ethical accounting, auditing and reporting. Accounting Forum, 25(3), 264-282.

Puxty, A. G. (1986). Social accounting as immanent legitimation: A critique of a technicist ideology. Advances in Public Interest Accounting, 1, 95-111.

Springett, D. (2003). Business conceptions of sustainable development: A perspective from critical theory. Business Strategy and the Environment, 12, p. 71-86.

Stewart, L. and Collins E. (2004). Sustainability Practices of New Zealand Business, Waikato University School of Management and the Sustainable Business Network.
Sustainable Business Network and Ministry for the

Environment (2003). Enterprise ${ }^{3}$ - Your Business and the Triple Bottom Line, Wellington: SBN \& MfE.

Tilt, C.A. (2001). The content and disclosure of Australian corporate environmental policies. Accounting, Auditing \& Accountability Journal, 14(2), 190-212.

Tilt, C. A. (1994). The influence of external pressure groups on corporate social disclosure: Some empirical evidence. Accounting, Auditing and Accountability Journal, 7(4), 47-72.

Tinker, T., Lehman, C. and Neimark, M. (1991). Falling down the hole in the middle of the road: Political quietism in corporate social reporting. Accounting, Auditing and Accountability Journal. 4(2), 28-54.

Trades Union Congress (1996). Your Stake at Work: TUC Proposals for a Stakeholding Economy, London: TUC.

Unerman, J. (2000). Reflections on Quantification in Corporate Social Responsibility Content Analysis. Accounting, Auditing and Accountability, 13(5). 667-680.

Walden, W.D. and Schwartz, B.N. (1997). Environmental Disclosures and Public Policy Pressures, Journal of Accounting and Public Policy, 16, 125-54.

WorkCoverSafety (1999). Occupational Health and Safety Reporting: Guidelines for Reporting OHS in Annual Reports.

World Business Council for Sustainable Development (2004). Employee Safety in the Cement Sector: A Guidebook for Measuring and Reporting. Geneva: WBCSD. 